\title{
KRITIK TERHADAP PANDANGAN JOEL B. GREEN MENGENAI MONISM
}

\author{
Pieter Kurnia ${ }^{1}$, Benyamin Fleming Intan ${ }^{2}$ \\ 12 STT Reformed Injili Internasional
}

Korespondensi: : Pieterkurnia@hotmail.com; Benyaminintan@sttrii.ac.id

\begin{abstract}
ABSTRAK: Green mengeklaim monism jauh lebih konsisten dibandingkan pemisahan tubuh dan jiwa atau dikenal dengan dualistis. Green mengatakan manusia adalah manusia utuh dan tidak memiliki aspek metafisik. Segala aspek "metafisik" seperti keinginan, kehendak, dan setiap keputusan terjadi karena dua hal. Pertama, adanya reaksi kimia di dalam otak atau akibat dari konsep neuroscience dan kedua, aspek relasi manusia. Green berusaha membuktikan hal tersebut dengan menggunakan teks-teks Alkitab dan pendekatan studi kata. Namun pandangan ini bermasalah karena menyebabkan identitas manusia hilang ketika mengalami kematian dan menjadi pribadi yang baru ketika dibangkitkan. Oleh sebab itu, artikel ini akan mengevaluasi klaim-klaim Green mengenai monism. Adapun evaluasi ini akan dikaji dan dibahas berdasarkan sudut pandang Reformed.
\end{abstract}

KATA KUNCI: Monism, neuroscience, dualistis, metafisik.

ABSTRACT: Green claims that monism is far more consistent than the separation of body and soul, also known as dualistic. Green said humans are whole humans and have no metaphysical aspects. All "metaphysical" aspects such as desire, will and every decision occur because of two things. First, there are chemical reactions in the brain or the result of neuroscience concepts and second, aspects of human relations. Green tries to prove this by using biblical texts and a word study approach. However, this view is problematic because it causes human identity to be lost when they die and become a new person when they are resurrected. Therefore, this article will evaluate Green's claims about monism. This evaluation will be reviewed and discussed from the Reformed point of view.

KEYWORDS: Monism, Neuroscience, Dualistic, Metaphysical. 


\section{Pendahuluan}

Pemisahan tubuh dan jiwa pada manusia menjadi kunci penting di dalam kebangkitan orang mati. Seorang yang dibangkitkan haruslah memiliki identitas yang sama dengan sebelumnya. Untuk bisa mempertahankan identitas yang sama ini diperlukan "sesuatu" yang bisa menjembatani hal tersebut. Sesuatu yang bisa mempertahankan Identitas tersebut adalah jiwa yang bersifat kekal. Kematian tidak membuat jiwa hilang selama-lamanya.

Namun pandangan adanya pemisahan tubuh dan jiwa mengalami tantangan dari Joel B. Green karena tidak ada dasar di dalam Alkitab. Ia menyarankan pandangan monism karena lebih konsisten dengan Alkitab. Di dalam bukunya Body, Soul, and Human Life, ia menyatakan bahwa "my analysis will demonstrate how the Bible can portray the human person as a single whole or unified being (some form of monism)..."1 untuk mendukung pemikiran manusia sebagai ontological monism, Ia mengutip dari John A.T. Robinson "Paul is 'a Hebrew of Hebrews,' as John A.T. Robinson put it, drawing attention to Paul's wholistic understanding of the human creature." ${ }^{2}$ Green mendefinisikan mengenai pemisahan tubuh dan jiwa atau dualistis yaitu

The default hermeneutical position by which many people today make sense of the Bible's anthropology is a dualist one. By dualism, I refer to the position that postulates, in addition to the body, a second, metaphysical entity, often called a soul or spirit, to account for human capacities and distinctives. ${ }^{3}$

Baginya, dualistis berarti di dalam manusia terdapat dua entitas yang berbeda yaitu yang pertama adanya aspek terlihat oleh pancaindra yang disebut tubuh dan kedua, yaitu aspek yang tidak terlihat oleh pancaindra atau metafisik yang disebut jiwa.

Berdasarkan definisi di atas, ia menyatakan bahwa dualistis ini harus ditolak karena "is generally not supported in the Christian Scriptures." ${ }^{4}$ Green mengusulkan bahwa "the Christian Scriptures bear witness to and are best understood in terms of a monist anthropology." ${ }^{5}$ Monism berarti tidak ada faktor metafisik seperti jiwa atau roh pada manusia. Manusia adalah utuh seutuhnya tanpa adanya pemisahan tersebut. Adapun Green memberikan definisi monism yang dia dukung adalah,

Various forms of monism defended among Christians require no second, metaphysical entity, such as a soul or spirit, to account for human capacities and distinctives,

\footnotetext{
Joel B. Green, Body, Soul, and Human Life, ed. Craig G. Bartholomew and Christopher R. Seitz, Studies in Theological Interpretation (Grand Rapids, MI: Baker Academic, 2008), 34 Ibid., 6 .

Joel B. Green, "Three Exegetical Forays Into The Body-Soul Discussion”, Criswell Theological Review, CTR 7/2 (Spring 2010), 3.

Ibid., 4 .

Ibid.
} 
while insisting that human behavior cannot be explained exhaustively with recourse to genetics or neuroscience. Using various models, the monists with whom I am concerned argue that the phenomenological experiences that we label "soul" are neither reducible to brain activity nor evidence of a substantial, ontological entity such as a "soul," but rather represent essential aspects or capacities of the self. ${ }^{6}$

Baginya aspek "jiwa" bukan berbicara mengenai aktivitas di otak (neuroscience) saja atau tingkah laku manusia yang tidak terlihat karena kedua hal tersebut tidak bisa menjawab masalah manusia secara utuh. Namun, kedua hal tersebut tidak boleh diabaikan karena merupakan hal yang esensi dari manusia. Faktor ini juga mempengaruhi kapasitas manusia di dalam memilih dan bertindak. Untuk mendukung pandangannya, Green menyatakan ada tiga teks Alkitab yang dianggap mendukung dualistis tetapi sebenarnya lebih mendukung kepada monism. ${ }^{7}$ Pertama adalah 1 Korintus 12:1-4, kedua, Matius 10:28 dan terakhir adalah Wahyu 6: 9-10.

Oleh sebab itu, penulis akan mengkritik argumentasi Green mengenai monism dan melakukan pembelaan bahwa pemisahan tubuh dan jiwa lebih konsisten dengan Alkitab. Di dalam artikel ini, penulis juga akan melakukan kajian dan pembahasan menurut teologi Reformed.

\section{Pandangan Green Mengenai Manusia}

Kerangka yang digunakan oleh Green untuk mendukung monism ini adalah adanya perkembangan ilmu sains yang juga berpengaruh kepada bidang teologi. Ia menjelaskan hubungan antara sains dengan teologi tersebut bahwa "science and religion could not be viewed as antagonists, for science was simply an investigation into God's creation." ${ }^{8}$ Dogmatik gereja tidak boleh langsung anti atau curiga terhadap kemajuan sains. Dia berargumen bahwa ada dua buku yaitu Alkitab dan dunia natural yang tidak perlu dipertentangkan. Ia mengutip dari Agustinus bahwa "some people read books in order to find God. But the very appearance of God's creation is a great book." He advised, "Ponder heaven and earth religiously." 9 Pemikiran bapak gereja tersebut mengakui bahwa buku ciptaan juga bisa menjelaskan keberadaan Allah, sang Pencipta. Atas dasar inilah, Green berpendapat bahwa antropologi manusia juga bisa dijelaskan dari buku ciptaan secara khusus melalui faktor perkembangan ilmiah. Oleh sebab itu, Green menyimpulkan bahwa "the two, science and theology, interact in a more organic way than we often acknowledge, with the result that it is virtually impossible to extricate the one influence from

\footnotetext{
Joel B. Green, Body, Soul, and Human Life, 31.

Joel B. Green, "Three Exegetical Forays Into The Body-Soul Discussion", 5

Joel B. Green, Joel B. Green, "Body and Soul, Mind and Brain," in In Search of the Soul: Four Views of the Mind-Body Problem, ed. Joel B. Green (Eugene, OR: Wipf \& Stock, 2010), 14

Joel B. Green, “Body and Soul, Mind and Brain”, 14.
} 
the other." ${ }^{10}$ Atas dasar inilah, ia menggunakan sains yaitu ilmu neuroscience supaya bisa memiliki tempat di dalam diskusi dengan Alkitab terutama di dalam doktrin manusia. Hal ini bisa ditemukan di dalam argumentasi yang dinyatakan untuk mendukung monism.

Berdasarkan penjelasan di atas, Green menyimpulkan konsep manusia yang berelasi - baik berelasi dengan Allah atau dengan alam. Oleh karena itu, bagi Green, relasi dengan alam juga penting sehingga pendekatan alam, khususnya aspek neuroscience tidak boleh diabaikan. Tuhan menciptakan manusia untuk bisa berelasi dengan benar dengan alam. Dengan Alkitab, manusia bisa berelasi dengan Allah dan dengan sains, manusia bisa berelasi dengan alam.

Untuk mendukung tesisnya, Green menggunakan contoh kasus bagaimana neuroscience sangat berhubungan dengan tingkah laku seseorang. Ia memberikan contoh yaitu seorang pengajar berumur 40 tahun yang mengalami kecanduan pornografi lalu berkembang menjadi seorang paedofil. ${ }^{11}$ Walaupun ia sudah berada di dalam panti rehabilitasi namun keadaan tidak berubah sehingga ia harus dimasukkan ke dalam penjara. Namun sebelum berakhir di penjara, sang pengajar ini setuju untuk diperiksa oleh tim dokter. Tim dokter menggunakan Magnetic Resonance Imaging (MRI) dan diketahui bahwa ada tumor sebesar telur yang berada di otak guru tersebut. Secara mengejutkan, perilaku seksualnya menjadi normal setelah tumor dikeluarkan. Namun demikian, dalam setahun perilaku seksualnya kembali menyimpang. Oleh sebab itu, tim dokter kembali melakukan MRI kepadanya dan didapati bahwa tumor tersebut kembali tumbuh. Setelah tumor tersebut diangkat kembali, perilakunya pun kembali normal.

Berdasarkan kasus ini, Green mengatakan bahwa keadaan manusia tidaklah mempunyai kebebasan memilih. Guru tersebut mengalami gangguan seksual dikarenakan terbelenggu sebagai akibat dari fungsi otaknya terganggu. Kemampuan memilih manusia terganggu oleh karena impuls pada otak terdapat tumor. ${ }^{12}$ Green mengkritik pandangan hanya di dalam jiwa saja manusia beroleh kemampuan untuk memilih dan memutuskan. Keadaan otak yang mengalami masalah juga menjadi faktor lain seorang manusia bisa memilih dan menentukan. Green berargumen mengenai persoalan tubuh dan jiwa terhadap kemampuan manusia ini.

The tightening of the mind-brain link in neuroscience renders more and more improbable the need for such an ontologically separate entity, and the reality that human self-consciousness is neurobiologically generated is an inescapable

\footnotetext{
Joel B. Green, "Body and Soul, Mind and Brain", 15.

Joel B. Green, Body, Soul, and Human Life, 73.

Joel B. Green, Body, Soul, and Human Life, 74.
} 
datum for Christian anthropology. ${ }^{13}$

Baginya, selain keadaan manusia yang sudah jatuh di dalam dosa, aspek sains yaitu neorobiology juga menjadi faktor lain bagaimana seorang manusia bisa memiliki kemampuan untuk memilih dan menentukan. ${ }^{14}$ Green menolak bahwa faktor jiwa sebagai satu-satunya aspek yang mendorong seseorang bisa memilih dan mengambil keputusan pada manusia.

Untuk melakukan membuktikan kesalahan pemisahan tubuh dan jiwa pada manusia, Green menggunakan tiga pendekatan yaitu teks Alkitab (1 Korintus 12:1-4, Matius 10:28 dan Wahyu 6:9-10) dan karikatur PL dan PB dan studi kata. Dari pendekatan ini, Green juga mendukung adanya neuroscience di dalam setiap tindakan manusia.

\section{Kritik Dualistis Berdasarkan Teks 1 Korintus 12:1-4}

Pertama, pada 2 Korintus 12:1-4 yaitu pengalaman Paulus di luar tubuh. Paulus memberikan pernyataan terkait pengalaman tersebut yaitu "entah di dalam tubuh entah di luar tubuh, aku tidak tahu, Allah yang mengetahuinya (12:2-3)." Green berkomentar mengenai kalimat tersebut "Paul himself not only recognizes but actually emphasizes - namely, that he simply does not know the status of his body during this episode." ${ }^{15}$ Oleh karena ketidaktahuan ini, Paulus tidak sedang menjelaskan adanya kemungkinan pemisahan tubuh dan jiwa. Green menjelaskan pengalaman keluar dari tubuh berdasarkan kemajuan ilmu pengetahuan. Ia mengatakan pengalaman tersebut "are typically brief episodes in which a person's conscious self seems to take leave of the body and to look back on the body as though it belonged to someone else."16 Dan pengalaman ini adalah pengalaman yang biasa terjadi oleh karena "generated in our bodies, by our brains." 17 Oleh sebab itu, pengalaman Paulus pada surat 2 Korintus tidak boleh langsung disimpulkan sebagai "ontologically distinct 'soul' or 'spirit' as a necessary component of an explanation for the phenomenal experience of being outside of one's body." ${ }^{18}$ Bagi Green, pengalaman Paulus ke Surga tidak membuktikan apapun mengenai pandangan dualistis. Ia menyimpulkan bahwa

Paul himself emphasizes his agnosticism regarding his embodied state during his heavenly journey, and comparative study has shown that the sort of ecstatic

13 Joel B. Green, “Eschatology and the Nature of Humans: A Reconsideration of Pertinent Biblical evidence", Science \& Christian Belief. S \& CB (2002), 14, 33-50

14 Joel B. Green, Body, Soul, and Human Life, 74-75

15 Joel B. Green, "Three Exegetical Forays Into The Body-Soul Discussion", 7

16 Ibid., 8

17 Ibid., 10

18 Ibid. 
experience the apostle recounts is explicable without recourse to an entity such as a human soul or spirit distinct from the body. ${ }^{19}$

\section{Kritik Dualistis Berdasarkan Teks Matius 10:28}

Kedua, pada Matius 10:28 “Dan janganlah kamu takut kepada mereka yang dapat membunuh tubuh, tetapi yang tidak berkuasa membunuh jiwa; takutlah terutama kepada Dia yang berkuasa membinasakan baik jiwa maupun tubuh di dalam neraka." Green menggunakan pendekatan Yesus sejarah untuk mengkritik pandangan dualistis. If one were to argue that Matt 10:28 testifies to body-soul dualism, this would not be the same thing as saying that the historical Jesus was an anthropological dualist..$^{20} \mathrm{Hal}$ ini karena Yesus berbicara menggunakan bahasa Aram sehingga tulisan Yunani pada Matius tidak bisa mewakili perkataan Yesus sebagai dualistis. Green menggunakan teks paralel yaitu Lukas 12:4-5 bahwa kata jiwa tidak muncul sebagai dukungan tidak adanya dualistis pada Yesus. Green berkomentar bahwa "Jesus as saying no more than that those who are persecuted should take comfort in knowing that' martyrdom is only the end of one's existence in this world, and not the ultimate end of one's life." ${ }^{21}$ Oleh sebab itu, pada teks Matius seharusnya kata "psyche [jiwa] in Matthew would refer not to "soul" but to 'vitality"'22

Selain itu, Green juga menggunakan latar belakang Helenistik untuk mendukung argumennya. Ia mengatakan bahwa

Given the sociocultural context of Judaism in the Second Temple period, we should not be surprised to find in the NT texts like Matt 10:28. The saying itself echoes the martyr-theology of such Hellenistic Jewish texts as Wis 16:13-14; 2 Mace 6:30, in which it is maintained that persecutors have access only to the body, but only God has power over the whole person. Accordingly, it is worth exploring whether such texts make use of a metaphorical rather than an ontological dualism, in which the "inner" and "outer" aspects of a human being are separated for the sake of mitigating the power of those who would persecute the faithful. ${ }^{23}$

Berdasarkan kutipan di atas, Green mengatakan hanya Tuhan saja yang berkuasa atas seluruh hidup manusia. Kata-kata yang digunakan pada Matius 10:28 hanyalah gaya bahasa saja dan tidak mendukung ontologi dualistis.

Green melanjutkan bahwa kata-kata yang mengacu kepada "body and soul in biblical usage refers to the totality of human personality, with either term,

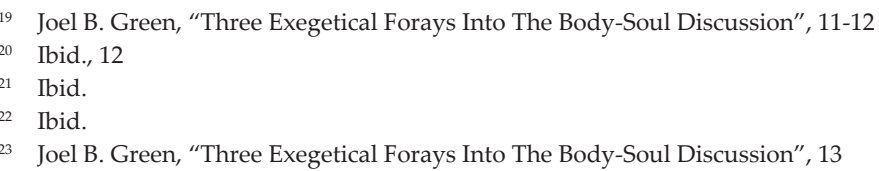


'body' or 'soul,' capable of describing the whole" 24 Begitu pun juga di dalam teks Matius bahwa kematian tubuh berarti kematian total. Membangun pemisahan tubuh dan jiwa tidak bisa hanya berdasarkan kata-kata di dalam Alkitab karena perlu latar belakang PB mengapa muncul perkataan tubuh dan jiwa yang seolah mendukung dualistis. Hal ini terjadi karena ada budaya retorika di dalam perkataan saat itu. Menurut Green, seseorang harus memperhatikan "the distinction between ontological and rhetorical dualisms must always be kept in mind, since biblical authors have employed conceptual and/or rhetorical distinctions as heuristic devices for speaking of what is in feet indivisible." ${ }^{25}$ Ia melanjutkan bahwa "inner" and "outer" or "body and "soul" - linguistic pairs such as these often have métonymie or synecdochic function, just as the pair in Scripture, "flesh and blood," does not designate two different parts of the human being but rather "human agency" (as opposed to divine). ${ }^{26}$ Oleh sebab itu, Green menyimpulkan kata tubuh (soma) maupun jiwa (psyche) tidak mengacu terminologi dualistis tubuh dan jiwa ... namun sebagai "metonymic or synecdochic senses." ${ }^{27}$ Maka Matius 10:28 harus dimaknai sebagai peringatan bahwa "God raises the dead, body and soul (i.e. the person in his or her totality), and for those who do not maintain faithfulness in the midst of persecution, God is capable of destroying even the life he has given." 28

\section{Kritik Dualistis Berdasarkan Teks Wahyu 6: 9-10}

Ketiga adalah Wahyu 6: 9-10. Sama dengan di atas kata jiwa (psyche) pada ayat ke-9 tidak bisa mengacu kepada pemisahan tubuh dan jiwa. Kata ini bisa mengacu kepada pribadi manusia secara utuh. Psyche refers to "life" in Rev 8:9; 12:11; 16:3; 18:13; and to one's seat of desires in 18:14. ${ }^{29}$ Berdasarkan argumen sebelumnya, Green menolak bahwa kata psyche mendukung adanya dualistis manusia karena ini mengacu kepada sinekdoke saja.

Pada bagian Wahyu ini, Green menggunakan teks lain yaitu Lukas 16:19-31 karena teks ini juga menceritakan kehidupan setelah kematian. Bagi Green, "the rich man is now suffering in Hades - not biding his time until the final judgment. Nor do Lazarus and the rich man appear as disembodied souls." ${ }^{\prime 30}$ Ia menyatakan tubuh orang kaya yang mengalami penyiksaan masih tetap ada oleh karena ia bisa merasakan kehausan. Baginya tidak ada aspek pemisahan tubuh dan jiwa karena orang kaya bisa merasakan kesakitan melalui

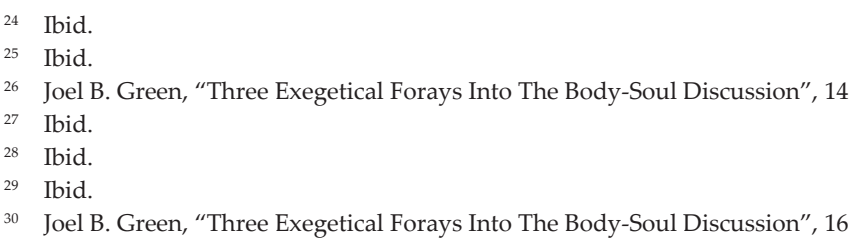


pancaindranya. Manusia tetap adalah manusia utuh dan tidak terbagi-bagi setelah mengalami kematian.

\section{Kritik Karikatur Pemikiran Ibrani dan Yunani}

Berdasarkan konsep PL, Green mengatakan "[i]ndeed, that the OT does not think of the human being as made up of or possessing 'parts' is often passed over quickly, as if it were an unassailable truism, in the service of other theological considerations." ${ }^{31}$ Bagi Green, manusia di dalam konsep PL tidaklah terpisah-pisah. PL menggunakan kata jiwa, tubuh, hati, telinga yang merujuk manusia secara pribadi. Mengapa terjadi pemisahan tubuh dan jiwa? Ia berargumen bahwa pandangan dualistis yang ada selama ini terjadi karena "consequence of unadulterated exegesis (i.e., read out of the text) or a philosophical-scientific assumption read into the text (i.e., eisegesis). ${ }^{32}$ Green meyakini bahwa manusia itu utuh adanya karena konsep Ibrani pada zaman tersebut mengajarkan demikian. Hal ini tentunya sesuai dengan Alkitab sehingga pandangan dualistis tidak benar karena para teolog memasukkannya ke dalam Alkitab.

Selain itu, ia mengatakan bahwa seharusnya manusia dilihat secara relasi dan bukan eksistensialis jika mengacu kepada konsep PL. Ia menyimpulkan bahwa

humanity is set within a relational nexus - with God, whose own activity in drawing humanity to himself constitutes the basis of human openness to God; and with other humans, with relationships determined by righteousness. The OT, too, recognizes sin as disruption, alienation, and falsehood among humans and in relation to $\operatorname{God}^{33}$

Green meminjam istilah dari Walter Brueggemann yaitu "The Human Person as Yahweh's Partner" ${ }^{34}$ sebagai dukungan bahwa manusia tidak bisa dilihat secara eksistensialis tetapi relasi kepada Allah. Oleh sebab itu, Green berpendapat manusia lebih indah jika dinyatakan secara relasi kepada Allah dibandingkan berkutat dengan aspek ontologi yaitu tubuh dan jiwa. ${ }^{35}$

Lalu bagaimanakah konsep Green mengenai natur manusia? Ia menggunakan titik awal di dalam Kejadian 1:27. Menggunakan konsep manusia secara eksistensialis bukanlah titik yang baik untuk mengerti natur manusia. Ia mengatakan bahwa manusia sebagai gambar dan rupa Allah diciptakan untuk bisa berelasi dengan Allah. Ia melanjutkan "humans are like other living

1 Joel B. Green, Body, Soul, and Human Life, 8.

2 Ibid., 26.

3 Joel B. Green, Body, Soul, and Human Life, 9.

34 Walter Brueggemann, Theology of the Old Testament: Testimony, Dispute, Advocacy (Minneapolis, MN: Fortress Press, 2005), 450.

35 Joel B. Green, Body, Soul, and Human Life, 9. 
things in their being created by God and thus in their relation to God." ${ }^{36}$ Manusia dan binatang sama-sama dibentuk dengan komposisi sama (Kejadian 1:30) dan diberikan perintah yang sama yaitu "to reproduce, increase, and fill the seas and the earth (Genesis 1:22)." 37 Tetapi Green melanjutkan perbedaan antara manusia dengan binatang bahwa "the additional vocation given humanity, 'to subdue' and 'to have dominion' over the earth (Genesis 1:26, 28)." ${ }^{38}$ Manusia adalah makhluk yang berelasi dengan ciptaan lainnya. Konsep manusia mendominasi ciptaan lain mendukung relasi tersebut. Selain itu, pemberian mandat secara langsung dari Allah menjadi pembeda dengan ciptaan lainnya. Green mengatakan bahwa "the human family has this responsibility in relation to God's creation because this is how God has made us." 39

Ia memberikan kesimpulan bahwa kitab Kejadian bukan berbicara manusia secara ontologi yaitu pemisahan tubuh dan jiwa tetapi relasi kepada Allah.

Genesis 1-2 does not locate the singularity of humanity in the human possession of a "soul," but rather in the human capacity to relate to Yahweh as covenant partner, and to join in companionship within the human family and in relation to the whole cosmos in ways that reflect the covenant love of God... Indeed, one might better translate Genesis 2:7 with reference to the divine gift of life: "the human being became fully alive"... It is profound in its presentation of the human person fundamentally in relational terms, and its assessment of the human being as genuinely human and alive only within the family of humans brought into being by Yahweh and in relation to the God who gives life-giving breath. That is, Genesis does not define humanity in essentialist terms but in relational, as Yahweh's partner, and with emphasis on the communal, intersexual character of personhood, the quality of care the human family is to exercise with regard to creation as God's representative, the importance of the human modeling of the personal character of God, and the unassailable vocation of humans to reflect among themselves God's own character. ${ }^{40}$

Green menyetujui bahwa yang paling utama di dalam diri manusia adalah relasi dan komunitas di tengah dunia. Relasi ini pun adalah anugerah Allah sebagai manusia.

Pada konsep PB, Green menggunakan latar belakang budaya Yunani untuk mendukung bahwa tidak ada satu kesimpulan yang sama mengenai pemisahan tubuh dan jiwa pada budaya Yunani. Ia mengatakan "Greek thought itself was more variegated on the nature of the soul than a reading focused on Plato (or on some first-century neo-Platonists) would allow." ${ }^{41}$ Konsep jiwa

36 Ibid., 61.

37 Ibid.

38 Ibid., 62.

39 Joel B. Green, Body, Soul, and Human Life, 61.

40 Joel B. Green, Body, Soul, and Human Life, 64. Penekanan ditambahkan.

41 Joel B. Green, Body, Soul, and Human Life, 51. 
sangatlah beragam dan tidak bisa menggunakan satu sumber saja untuk mewakili latar belakang budaya Yunani tersebut. Ia mengatakan "sharply put, there was no singular conception of the soul among the Greeks, and the bodysoul relationship was variously assessed among philosophers and physicians in the Hellenistic period." 42 Jika tidak ada satu pun konsep yang sama di tengah para filsuf Yunani maka tidak bisa menyimpulkan bahwa faktor latar belakang budaya Yunani bisa menjadi acuan dalam langsung menyimpulkan dualistis tubuh dan jiwa.

\section{Kritik Berdasarkan Pendekatan Studi Kata}

Green tidak setuju bahwa dengan hanya mengacu satu kata dari bahasa asli bisa mewakili seluruh konsep manusia. Green berpendapat bahwa di dalam ilmu linguistik suatu kata hanya bisa memiliki arti yang benar berdasarkan konteks penulisan. Dalam manusia, banyak kata bahasa asli yang biasa digunakan untuk menjelaskan manusia yaitu "Hebrew terms such as nepheš, bāśār, lēb, and rūah and Greek terms such as sōma, psychē, pneuma, and sarx." ${ }^{43}$ Studi kata-kata tersebut juga memiliki banyak arti berdasarkan konteks penulisan. Kita tidak bisa melepaskan satu kata saja untuk mendapatkan definisi karena satu kata tersebut tidak terlepas dari konteks kalimat. Green mengatakan

Thus, depending on context, nepheš, though often identified with the idea of a "soul," might be translated into English as "life," "person," "breath," "inner person," "self," "desire," or even "throat." Bāśār might be translated with the English terms "flesh," "body, "meat," "skin," "humankind," or "(the) animal (kingdom)." Translations of leb might include "heart," "mind," "conscience," and "inner life." Finally, rūah might be taken as a reference to "wind," "breath," "seat of cognition and/or volition," "disposition," "spirit," or "point on a compass." 44

Kata yang sering digunakan adalah nephesh di dalam PL dan $p s y c h e$ di dalam PB. Green menjelaskan kata nephes bahwa

occurs almost 800 times, with the primary meaning of "throat" or "gullet" (very much a physical referent!), and with the extended sense of "vitality" or "the impulse of life over against death." When used anthropologically, its typical reference is to the entire human being, and not to some portion of the person." 45

Begitu juga dengan kata psyche "might wish to translate as 'soul,' actually means 'soul' (or requires an identification with the concept of 'soul'), defined as the

\footnotetext{
Joel B. Green, Body, Soul, and Human Life, 53.

Ibid., 54 .

Ibid.

Joel B. Green, Body, Soul, and Human Life, 57.
} 
spiritual part of a human distinct from the physical or as an ontologically separate entity constitutive of the human 'self.' 46

Bagi Green, studi kata semantik baik dari kata Ibrani maupun Yunani sangat terbatas dan negatif. Untuk mendukung penjelasannya, Green menggunakan surat 1 Petrus.

Peter deploys the expected range of terms associated with the nature of the human person. He uses sōma ("body") only once, in 2:24, with reference to Christ's having borne "our sins in his body on the tree."... Sarx ("flesh, body") refers to "humanity" in 1:24, and otherwise refers to life as a human in 3:18, 21; 4:1 (2×), 2, 6. Psychē ("life, vitality," sometimes translated as "soul") appears

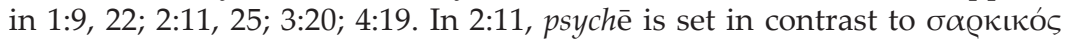
(sarkikos, "belonging to this world"), but it never appears in relation to sarx. (Sarx is juxtaposed with pneuma ["spirit"] in 3:18; 4:6, however.) Christ is the guardian of the Christian's psychē in 2:25, just as God is guarding "you" for a salvation ready to be revealed at the last time. Those who suffer entrust their psychai (plural) to God (4:19). In 3:20, psychè refers to "persons," Noah and his kin, rescued through the flood. For Peter, sarx concerns "life as it reflects and/or pertains to this world" and psychè connotes "life as it reflects and/or pertains to the world to come." ${ }^{\prime \prime 7}$

Green menyimpulkan bahwa Petrus bisa menggunakan kata soma, sarx, dan psyche yang mengacu kepada suatu konsep yang berbeda sesuai dengan konteks penulisan. Tidak selalu kata-kata tersebut diartikan secara ontologi dan menjadi dasar antropologi manusia.

Consequently, the idea that one could simply pile up all of the references in Scripture to "body" or "soul," and from this deduce "the biblical understanding of the human person" is misguided on linguistic grounds. We must face the reality that neither the Old nor the New Testament writers developed a specialized or technical, denotative vocabulary for theoretical discussion of the human person. ${ }^{48}$

\section{Evaluasi Terhadap Pandangan Green}

\section{Evaluasi Berdasarkan Teks 2 Korintus 12:1-4}

Green mendukung pandangan monism dengan menyatakan bahwa Surat 2 Korintus 12:1-4 adalah pengalaman "out of body". Baginya, Paulus pada surat 2 Korintus tidak boleh langsung disimpulkan sebagai "ontologically distinct 'soul' or 'spirit' as a necessary component of an explanation for the phenomenal experience of being outside of one's body." ${ }^{49}$

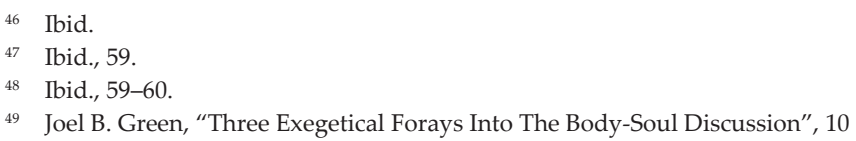


Green menyimpulkan demikian tanpa melakukan eksegesis terhadap teks tersebut. Ia hanya melakukan pendekatan neuroscience untuk menjawab pengalaman Paulus berada di 'luar tubuh (ayat 2 dan 3)'. Ia memasukkan konsep sains ke dalam teks tersebut untuk mendukung pandangan monismnya, Green selama ini menuduh bahwa pandangan dualistis terjadi karena "consequence of unadulterated exegesis (i.e., read out of the text) or a philosophical-scientific assumption read into the text (i.e., eisegesis)." Namun, Green sendiri melakukan hal yang sama. Ia tidak melakukan eksegesis pada ayat-ayat tersebut tetapi ia memaksakan konsep monism masuk ke dalam teks tersebut untuk menyangkali pemisahan tubuh dan jiwa. Dengan menggunakan pendekatan sains untuk interpretasi ulang teks tersebut maka Green sendiri melakukan eisegesis pada teks tersebut.

Berbeda dengan Green, Cooper melakukan analisis terhadap teks tersebut. Ia mengatakan "the option of personal separation from the body is beyond dispute. For the Greek prepositions employed, ektos (v. 2) and chōris (v. 3), denote distancing and local separation. The possible absence of the mystical subject from his body is thus emphasized in Greek." ${ }^{50}$ Selain itu, Cooper menggunakan teks 2 Korintus 5:1-10 sebagai dasar Paulus tidak mendukung immediate resurrection. ${ }^{51}$ Dukungan terhadap pandangan monism sangat kurang karena monism mengasumsikan immediate resurrection sedangkan berdasarkan teks ini tidak demikian. Oleh sebab itu, Paulus memang setuju dengan pandangan dualistis daripada monism.

\section{Evaluasi Berdasarkan Teks Matius 10:28}

Yesus berkata bahwa “... dan janganlah kamu takut kepada mereka yang dapat membunuh tubuh, tetapi yang tidak berkuasa membunuh jiwa; takutlah terutama kepada Dia yang berkuasa membinasakan baik jiwa maupun tubuh di dalam neraka. (Matius 10:28). Berdasarkan ayat ini, Yesus memberikan pembeda antara tubuh $(\sigma \tilde{\omega} \mu \alpha)$ dan jiwa $(\psi v \chi \eta \dot{\eta})$. Yesus menegaskan untuk lebih takut kepada siapa yang memiliki kuasa membunuh jiwa. Secara sekilas, Yesus mendukung ide mengenai dualistis pada natur manusia.

Tetapi Green menolak kesimpulan pandangan dualistis tersebut dari teks di atas. Ia menggunakan Lukas 12:4-5 "Aku berkata kepadamu, hai sahabat-sahabat-Ku, janganlah kamu takut terhadap mereka yang dapat membunuh tubuh dan kemudian tidak dapat berbuat apa-apa lagi ... Takutilah Dia, yang setelah membunuh, mempunyai kuasa untuk

\footnotetext{
50 John W. Cooper, Body, Soul, and Life Everlasting, 149. Lihat C. K. Barrett, Commentary on the Second Epistle to the Corinthians (New York: Harper and Row, 1973), 308-309.

51 Ibid., 141-49. Lihat Paul R. Williamson, Death and the Afterlife, 89- 91 untuk argumen mendukung intermediate state.
} 
melemparkan orang ke dalam neraka. Baginya teks Lukas bisa menjelaskan maksud pembedaan tubuh dan jiwa pada teks Matius. Ia menyimpulkan perkataan Yesus sebagai kalimat penghiburan bagi siapa yang dianiaya karena kehidupan di dalam dunia tidaklah menjadi hal yang terutama.

Green juga menggunakan latar belakang Helenistik untuk mendukung pendapatnya. Ia menjelaskan bahwa hanya Tuhan saja yang bisa menghancurkan seluruh kehidupan manusia. Manusia hanya bisa berkuasa atas tubuh yang terlihat. Oleh sebab itu tidak boleh perkataan Yesus pada Matius 10:28 mengacu kepada ontologi dualistis. Green mengatakan bahwa Yesus menggunakan pembedaan tubuh dan jiwa hanya sebatas retorika dualistis saja oleh karena pengaruh dari budaya saat itu atau majas sinekdoke. Selain itu, ia juga menggunakan pendekatan historis bahwa Yesus berkata di dalam bahasa Aram sehingga tidak mungkin Yesus menyatakan di dalam konsep pembedaan tubuh dan jiwa.

Menjawab argumentasi Green maka Cooper yang menegaskan bahwa teks ini justru mendukung dualistis. Pendekatan bahwa tubuh dan jiwa berada di dalam sinekdoke tidaklah benar. For starters, synecdoche can be ruled out; each term cannot stand for the whole bodily person in this text. ${ }^{2}$ Pendekatan ini membuat teks menjadi tidak dimengerti karena jika mengikuti argumentasi tersebut maka menjadi "... dan janganlah kamu takut kepada mereka yang dapat membunuh manusia, tetapi yang tidak berkuasa membunuh manusia; takutlah terutama kepada Dia yang berkuasa membinasakan baik manusia maupun manusia di dalam neraka. (Matius 10:28, penekanan ditambahkan). Sangat aneh! Oleh sebab itu, Cooper melanjutkan bahwa Yesus sengaja melakukan pembedaan tubuh dan jiwa pada teks tersebut. Ia mengatakan "for whatever soul is, it can exist before God without the body, whatever it is. 'Body' and 'soul' cannot both be referring to the same thing in different ways. A human without a body is not the same as a human with a body, no matter how these words are defined." 53

Larry J. Waters mengutip kesimpulan Leon Morris mengenai teks ini. Ia menyatakan bahwa teks ini mendukung adanya pemisahan tubuh dan jiwa.

If Jesus had meant that the material body is the complete person, why did He not use another construction? Instead He separated the material from the nonmaterial, and referred to the two as distinct parts of the complete person. "Jesus [says] that God can destroy both soul and body in hell (cf. Isa. 10:18).... The expression refers to the whole person, and the whole person is body and soul.... Jesus is speaking of the destruction of all that makes for a rich and meaningful life, not of the cessation of life's existence. ${ }^{\prime 54}$

52 John W. Cooper, Body, Soul, and Life Everlasting, 117.

53 John W. Cooper, Body, Soul, and Life Everlasting, 117.

54 Leon Morris, The Gospel according to Matthew (Grand Rapids: Eerdmans, 1992), 263. Penekanan 
Maka penjelasan Green walaupun menggunakan budaya Helenistik yang mengatakan bahwa tubuh dan jiwa mengacu kepada keseluruhan haruslah ditolak karena menyebabkan kalimat pada Matius tidak memiliki makna. Walaupun kata jiwa ( $\psi v \chi \eta \dot{)}$ ) memiliki banyak arti tetapi Cooper menjelaskan bahwa berdasarkan teks Matius kata jiwa bukan mengacu kepada person namun "admittedly Matthew 10:28 does not explicitly define soul as "person" rather than mere "life-principle." 55 Seharusnya argumentasi bahwa tubuh dan jiwa mengacu kepada keseluruhan manusia haruslah ditolak.

Cooper juga menggunakan konsep kata gahenna (neraka) yang muncul pada teks tersebut yang sebenar kata tersebut "is not part of Old Testament eschatology but a product of the intertestamental period." 56 Dengan menggunakan kata tersebut, Matius mau menyatakan sesuai dengan konteks budaya saat itu bahwa "most Jews who spoke of Gehenna were holistic dualists. They believed that souls - persons - exist temporarily without bodies but that both "parts" will be reunited for eternity." ${ }^{57}$ Penjelasan Cooper jauh lebih konsisten berdasarkan budaya Yahudi saat itu karena kata gahenna yang mendukung adanya dualistis.

\section{Evaluasi Berdasarkan Teks Wahyu 6:9-10}

Green menolak kata jiwa $(\psi v \chi \eta \dot{)}$ mendukung dualistis pada manusia. Ia menggunakan argumentasi sebelumnya bahwa kata ini mengacu kepada pribadi manusia secara utuh namun tidak berada di dalam kondisi intermediate state.

Pada pasal ini menjelaskan adanya kata jiwa $(\psi v \chi \eta \dot{)})$ yang berdasarkan konteks mengacu kepada orang-orang kudus yang sudah mati. Mereka yang sudah mati masih menunggu pembalasan atas kematiannya dan berseru kepada Allah. Cooper menjelaskan bahwa mereka menunggu kebangkitan berdasarkan teks Wahyu 20:5-6.

Walaupun demikian, Cooper sendiri mengalami kesulitan apakah teks ini mendukung monism atau dualistis. Namun ia menggunakan literatur Yahudi bahwa "one thing is clear: psyche is used in the apocalyptic genre to refer to humans in the intermediate state." 58

Seorang teolog setuju dengan adanya intermediate state berdasarkan teks Wahyu ini. Ia mengatakan "The book of Revelation, in which John twice locates the souls of martyrs (Revelation $6: 9-11 ; 20: 4-5$ ) in heaven prior to final

\footnotetext{
tidak ditambahkan. Dikutip dalam Larry J. Waters, "The Believer's Intermediate State after Death," Bibliotheca Sacra 169, no. 673-676 (2012): 291.

55 John W. Cooper, Body, Soul, and Life Everlasting, 118.

56 Ibid.

57 John W. Cooper, Body, Soul, and Life Everlasting, 118.

58 Ibid., 117.
} 
resurrection and judgment (Revelation 20:11-15), may also allude to an intermediate state." ${ }^{59} \mathrm{Hal}$ ini juga sesuai dengan pandangan teologi Reformed bahwa adanya konsep intermediate state dan para martir sedang menunggu kebangkitan tubuh

Beale, seorang teolog Reformed yang ahli di dalam PB, menjelaskan juga konsep intermediate state dan pemisahan tubuh dan jiwa pada teks ini. Dikatakan bahwa

That believers' physical death translates them directly into a state of spiritual resurrection is also indicated by Rev. 6:9-11, where saints are portrayed as "souls" without physical bodies under the heavenly altar and are told to "rest" a while until the full number of their fellow believers on earth also die ${ }^{60}$

Berdasarkan ketiga teks yang digunakan oleh Green, sangat tidak masuk akal jika ketiga teks ini menjadi dasar argumen yang kuat mendukung monism. Kesimpulan yang ada malah mendukung adanya aspek dualistis pada manusia dan menolak monism.

\section{Evaluasi Karikatur Pemikiran Ibrani dan Yunani dan Studi Kata}

Kritik yang dilontarkan oleh Green berdasarkan kedua hal di atas tidaklah masuk akal. Karena jika mengikuti argumentasi Green akan berakhir kepada nihilisme. Green melakukan dekonstruksi kata demi kata dan meminta kata didefinisikan berdasarkan konteks karena di dalam kata tersebut juga memiliki definisi umum. Kita tidak bisa menentukan mana yang benar dan salah di dalam budaya ataupun kata yang digunakan. Latar belakang budaya dan setiap kata yang digunakan untuk menyatakan manusia tentunya memiliki maksud dan tujuan. Oleh sebab itu, pendekatan studi kata dan latar budaya Ibrani dan Yunani tidak bisa terhindarkan untuk melakukan analisis mengenai pemisahan tubuh dan jiwa.

Memang diakui bahwa suatu kata bisa memiliki berbagai makna sesuai dengan konteksnya. Namun bukan berarti kita tidak bisa mendapatkan sesuatu dari pendekatan tersebut. Adapun studi kata yang digunakan untuk menentukan manusia bukanlah hanya satu-dua kata saja tapi kepada setiap kata yang mengacu kepada manusia. Hasil dari analisis tersebut menyimpulkan bahwa manusia terbagi dua yaitu tubuh dan jiwa namun tetap utuh. Kata-kata yang memiliki sinekdoke tidak berarti tidak ada pemisahan tubuh dan jiwa.

59 Paul R. Williamson, Death and the Afterlife, 60.

60 G. K. Beale, The Book of Revelation: A Commentary on the Greek Text, New International Greek Testament Commentary (Grand Rapids, MI; Carlisle, Cumbria: W.B. Eerdmans; Paternoster Press, 1999), 1010 . 
Cooper mengkritik pandangan monism yang terlalu menekankan aspek keutuhan manusia pada PL dan melupakan aspek tubuh dan jiwa di dalam PB.

modern monists also have their ways of glossing over the differences between the Testaments. They interpret the anthropology of the Old Testament monistically and minimize its view of the afterlife. They then proceed to read the New Testament as though its anthropology were identical with the Old Testament view $^{61}$

Di dalam PB sangat menekankan ada pemisahan tubuh dan jiwa dan mereka tetap ada setelah kematian.

\section{Kesimpulan}

Penulis menyimpulkan bahwa pandangan monism Green didukung terhadap dua hal. Pertama, bahwa manusia harus dilihat dari aspek relasi bukan ontologi. Green berpendapat bahwa manusia lebih mengacu kepada aspek relasi dibandingkan dengan eksistensialis. Kedua, adanya peran neuroscience di dalam manusia yang tidak boleh diabaikan.

Untuk yang pertama, Green menyatakan bahwa manusia adalah makhluk yang berelasi baik kepada Allah, sesama, maupun ciptaan lainnya. Penjelasan bahwa manusia di dalam aspek ontologi manusia yaitu tubuh dan jiwa harus ditolak oleh karena manusia dan binatang sama-sama dibentuk berdasarkan komposisi yang sama (Kejadian 1:30). Perbedaan justru terjadi di dalam aspek relasi yaitu manusia menguasai ciptaan lainnya (Kejadian 1:26, 28). Oleh sebab itu, ia menolak bahwa pandangan dualistis sebagai dasar natur manusia. Sejak penciptaan, Allah menyatakan manusia sebagai makhluk yang berelasi. Dan bagi Green, konsep dualistis mirip dengan pemikiran Yunani.

Berdasarkan argumentasi di atas, maka penulis akan melakukan evaluasi terhadap pandangan Green. Pandangan Alkitab juga setuju adanya aspek relasi namun juga menegaskan pembedaan antara tubuh dan jiwa pada natur manusia. Di dalam teologi Reformed juga tidak menolak aspek kesatuan di dalam pribadi manusia. Selain itu, teologi Reformed juga setuju bahwa yang membedakan manusia dengan binatang bukanlah di dalam aspek jiwa (nefes) tetapi relasi dengan Allah.

Seharusnya Green tidak perlu alergi bahwa jika mendukung konsep dualistis maka mendukung pemikiran Yunani pada Alkitab. Hal itu tidaklah demikian, karena Alkitab adalah wahyu Allah yang penuh dengan kebenaran. Alkitab menggunakan bahasa Yunani bukan berarti setuju seluruh 
budaya Yunani. Alkitab bisa saja mengoreksi budaya yang salah dan menyatakan mana yang benar (2 Timotius 3:16). Tuhan Allah bisa menggunakan konsep budaya pada saat itu untuk menjelaskan bahwa kebenaran yang menyeluruh dan sejati. Sebagai contoh, hukum Hammurabi. Budaya ini sudah dikenal ratusan tahun sebelum Taurat Musa ada. ${ }^{62}$ Namun Allah memakai konsep hukum Hammurabi ini untuk menunjukkan kebenaran sejati dari konsep tersebut. Contoh, Musa menuliskan konsep mata ganti mata, gigi ganti gigi di dalam konsep mengasihi..$^{63}$

Kedua, terkait peran neuroscience. Memberi tempat sains di dalam manusia membuat sains sejajar dengan kebenaran Firman Tuhan. Penulis mempercayai bahwa Alkitab lebih melimpah dibandingkan jawaban hanya dari sains saja. Sedangkan Green mempercayai bahwa Allah adalah Pencipta dari alam sehingga alam (sains) pun bisa menjawab permasalahan antropologi manusia. Hal ini tidaklah benar karena membuat Alkitab setara dengan apa yang dijelaskan sains.

Pernyataan Green bahwa fungsi atau aktivitas pada otak berpengaruh kepada keputusan manusia perlu dipertimbangkan ulang karena memunculkan dilema baru. Ia memberikan contoh kasus seseorang paedofil untuk mendukung tesisnya. Tindakan, emosi, dan perasaan seseorang semata-mata oleh karena yang ada di dalam manusia yaitu biologi (kimia atau saraf yang berada di dalam otak) saja. Walaupun Green tidak mengatakan dan tidak mengakuinya tetapi ia berusaha mereduksi manusia menjadi materi atau mesin saja.

Jika mengacu kepada konsep tersebut maka akan memunculkan masalah baru yaitu dilema manakah tindakan, emosi atau perasaan apa saja dari seseorang yang dipengaruhi oleh faktor biologi (atau internal) dan mana yang dipengaruhi oleh aksi reaksi dari lingkungan sekitar? Green juga setuju bahwa faktor lingkungan dan komunitas mempengaruhi tindakan seseorang. Namun relasi antara keduanya tidak dijelaskan. Maka dilema muncul, manakah yang terlebih dahulu, apakah faktor aksi reaksi manusia terhadap lingkungan atau faktor biologi yang mempengaruhi seseorang bertindak? Dilema ini membawa kita terhadap permasalahan ayam dan telur. Tidak ada jawaban sains yang tepat untuk menjawab hal ini. Penulis percaya bahwa tindakan, perasaan dan emosi bahkan identitas pada manusia dipengaruhi oleh faktor metafisik (jiwa) di dalam manusia.

\footnotetext{
62 Joel Hamme Bryan C. Babcock and Justin David Strong, "Hammurabi, Code of," ed. John D. Barry et al., The Lexham Bible Dictionary (Bellingham, WA: Lexham Press, 2016).

63 R. Alan Cole, Exodus: An Introduction and Commentary, vol. 2, Tyndale Old Testament Commentaries (Downers Grove, IL: InterVarsity Press, 1973), 177.
} 
Cooper menyadari juga adanya penemuan sains mengenai "that states of consciousness and mental events are heavily dependent on what goes on in the brain." 64 Bahwa tindakan, pikiran, sensasi dan emosi dipengaruhi oleh faktor kimia dan stimulan elektrik pada otak. Namun ini hanya hipotesis saja karena tidak ada korelasi yang utuh terkait kedua hal ini. Cooper menegaskan bahwa

it is not even certain whether there is complete correlation between brain events and specific states of consciousness. The brain seems to function like a vast corporation in which millions of specific events all connected in large networks are required for a single thought or feeling ${ }^{65}$

Cooper menjelaskan mustahil bagi sains bisa menjawab segala tindakan, pikiran, dan perasaan manusia. Ia mengutip dari Donald MacKay bahwa

And if a certain part of the brain is damaged, other parts can take over to make mental activities still possible. Furthermore, the sheer number of brain cells and complexity of the brain itself, as well as the complex interactions of brain cells connected with any particular mental state, make the mapping of mental states onto clearly defined brain states a practical impossibility. ${ }^{66}$

Selain itu, Cooper melanjutkan bahwa manusia bukanlah makhluk yang pasif. Jika manusia melakukan tindakan aktif seperti berpikir dan berdoa maka aktivitas otak juga mengalami perubahan.

If subjects initiate some mental act like thinking or imagining something, changes in brain activity can be discerned. Here it is reasonable to assume that the mind has affected the brain. In other words, the hard empirical data are that there are two different kinds of events - mental and physiological-each of which appears to be able to affect the other. ${ }^{67}$

Hubungan aksi reaksi dari tindakan seseorang dengan aktivitas otaknya, yaitu kimiawi dan impuls saraf, tidak bisa dibuktikan dan sangat kompleks sekali. Maka contoh kasus yang dinyatakan oleh Green dan membuat seolah-olah sains bisa menjawab permasalahan manusia sungguh tidak benar. Green justru berusaha mereduksi manusia hanya karena akibat kegiatan otak saja.

Masalah lain adalah determinism. Jika neurobiologi atau sains bisa menjelaskan keseluruhan tindakan, pikiran dan perasan manusia maka manusia menjadi mesin yang terprogram sesuai dengan apa yang di dalam otak. Manusia tidak lagi menjadi bebas melakukan namun di kontrol oleh faktor

64 John W. Cooper, Body, Soul, and Life Everlasting, 205.

65 Ibid., 206.

66 Donald MacKay, Brains, Machines, and Persons (Grand Rapids: Eerdmans, 1980), 33-34. Dikutip dalam John W. Cooper, Body, Soul, and Life Everlasting, 206.

67 John W. Cooper, Body, Soul, and Life Everlasting, 207. 
biologi. Tentunya Alkitab menyatakan kepada kita bahwa manusia memiliki kehendak bebas.

Oleh sebab itu, Penulis menyimpulkan pandangan monism tidak sesuai dengan kebenaran Alkitab dan perlu ditolak. Pandangan pemisahan tubuh dan jiwa jauh lebih konsisten dengan Alkitab.

\section{Daftar Pustaka}

Babcock, Joel Hamme Bryan C. and Justin David Strong, "Hammurabi, Code of," ed. John D. Barry et al., The Lexham Bible Dictionary (Bellingham, WA: Lexham Press, 2016).

Beale, G. K. The Book of Revelation: A Commentary on the Greek Text. New International Greek Testament Commentary. Grand Rapids, MI; Carlisle, Cumbria: W.B. Eerdmans; Paternoster Press, 1999.

Brueggemann, Walter. Theology of the Old Testament: Testimony, Dispute, Advocacy. Minneapolis, MN: Fortress Press, 2005.

Cole, R. Alan. Exodus: An Introduction and Commentary. Vol. 2. Tyndale Old Testament Commentaries. Downers Grove, IL: InterVarsity Press, 1973. Cooper, John W. Body, Soul, and Life Everlasting: Biblical Anthropology and the Monism-Dualism Debate. Grand Rapids, MI; Cambridge, U.K.: William B. Eerdmans Publishing Company, 2000.

Green, Joel B. Body, Soul, and Human Life: The Nature of Humanity in the Bible. Edited by Craig G. Bartholomew and Christopher R. Seitz. Studies in Theological Interpretation. Grand Rapids, MI: Baker Academic, 2008. ed. In Search of the Soul: Four Views of the Mind-Body Problem. Eugene, OR: Wipf \& Stock, 2010.

“Three Exegetical Forays Into The Body-Soul Discussion", Criswell Theological Review, CTR 7/2 (Spring 2010), 3-18

, "Eschatology and the Nature of Humans: A Reconsideration of Pertinent Biblical evidence", Science \& Christian Belief. S \& CB (2002), $14,33-50$

MacKay, Donald. Brains, Machines, and Persons Grand Rapids: Eerdmans, 1980

Waters, Larry J. “The Believer's Intermediate State after Death," Bibliotheca Sacra 169, no. 673-676 (2012): 291.

Williamson, Paul R. Death and the Afterlife: Biblical Perspectives on Ultimate Questions. Edited by D. A. Carson. Vol. 44. New Studies in Biblical Theology. London; Downers Grove, IL: Apollos; InterVarsity Press, 2017. 